\title{
Farmer Decision on Cocoa Farm in North Lombok, Indonesia
}

\author{
Taslim Sjah ${ }^{1,2, *}$, Ridwan $^{1}$, Ibrahim ${ }^{1}$, Sri Supartiningsih ${ }^{1}$, Padusung ${ }^{1}$ \\ ${ }^{1}$ Faculty of Agriculture, University of Mataram, Mataram, Indonesia, 83125 \\ ${ }^{2}$ Study Program of Dryland Agriculture, Postgraduate Study, University of Mataram, Mataram, Indonesia, 83125 \\ *Corresponding author. Email: taslim.sjah@unram.ac.id
}

\begin{abstract}
Agricultural land in North Lombok, Indonesia, provides farmers with several choices of crops to be grown, among others is cocoa. However, farmer reasons for growing this crop is not completely documented. This paper explores farmer reasons for growing the crop and models their decisions. This paper used secondary data and field observation to serve the study objectives. The unit of analysis is cocoa grower in North Lombok. Data were analyzed in a descriptive way, providing farmer reasons or motives for growing the crop and building models to bridge farmer decisions in growing the chosen crop. This study found that there are three reasons that guide farmers into growing cocoa, i.e. income, social relation, and available time. These three reasons are then utilized to build the farmer decision model for the crop choice. The model indicates that cocoa growers are rational. This result also implies for extension activities, to be implemented in an effective way.
\end{abstract}

Keywords: Cocoa farm, Decision model, Farmer decision

\section{INTRODUCTION}

Agricultural sector has been one of the important sectors for many years in supporting Indonesian economic development. The development has been to increase agricultural production and recently become more specific rather than just increasing production alone, for example the program of food sovereignty, by fulfilling demand of foods through domestic production, self-regulating food policy, protecting and prospering farmers as the main actor of agricultural activities [1-3].

The government of Indonesia has the strategy for putting agriculture as the mover in Indonesian development. In practice, the position is meant to: (1) achieve self-reliance in rice, corn, soybean, chili, onion, increase the productions of sugar and meat; (2) diversify foods: (3) increase added value and competitiveness of export commodities and import substitution; (4) proving raw materials for bio industry and bio energy; (5) increase income of farm families; and (6) accounting to quality government official performance. [3]. Therefore, the sector of agriculture is not only important for itself but also for other sectors and for the country of Indonesia.
Important efforts for achieving the strategy, include the following: (1) improving land availability and usage; (2) improving agricultural facilities; (3) developing seeds; (4) improving farmer institutions; (5) improving financing; (6) developing bio industry and bio energy; and (7) expanding market for agricultural products [3]. In essence, these efforts are the same as implementing agribusiness, i.e.implementing agriculture from upstream to downstream, including the sub system of supporting agribusiness [4-6]. With the agribusiness approach, it is expected that the impact of the development becomes higher than the separated implementation of each sub system of agribusiness [6, 7].

The North Lombok government develops its agriculture based on its land resources and climate [8]. This is in line with the first mentioned effort above. To use the land with higher impact than before or currently, the government of North Lombok has also been implementing other strategies mentioned above for developing its agriculture, improving the livelihood of its people, and advancing its region. Developing agriculture by the government of North Lombok Agriculture is grounded on the nature that different locations or regions grow different plants or crops that their nature is supporting [9-11]. One of the crops that farmers grow in North Lombok Regency (in the province 
of West Nusa Tenggara) is cocoa. The production of cocoa in 2020 in North Lombok Regency was 450,358 $\mathrm{kg}$ [12]. By nature and people's conditions, cocoa is not the only choice available to farmers in the region $[12,13]$. Yet, many farmers in North Lombok choose this crop, for one or more reasons [14].

Understanding stakeholders' motivations or reasons and needs in a development program (programs) is important for a successful implementation of the $\operatorname{program}(\mathrm{s})$. Several literatures have indicated and prescribed this. One of the examples was the importance of motivation for businesses to grow in the market and that motivations are linked to the needs of the people and market [15]. Another is shown that successful implementation for many programs is largely dependent particularly upon motivation of the implementing staff and also highlighted the importance of meeting the needs of the programs [16]. The importance of motivation, in particular the intrinsic one, was also highlighted in adoption of new systems and programs [17].

For gaining understanding on the behavior of cocoa farmers and in considering the importance of the understanding, this paper explores farmers' decisions in farming cocoa in North Lombok Regency. The results of the exploration are then utilized to build a model of decisions that cocoa growers made. It is expected that this study will be useful at least in developing extension programs to cocoa producers and in making governmental policy for developing cocoa production and its product derivatives.

\section{MATERIALS AND METHOD}

This study applies qualitative research [18-20] on decision making by cocoa growers in North Lombok, with positive analysis [21, 22] on describing and explaining the decisions that people made. Unit of analysis in this study was an individual cocoa farmer in North Lombok. Data for this study were obtained from secondary sources, particularly from Sabdi (2016), who studied factors affecting farmer decision in a cocoa farm in North Lombok Regency. The method of data collection by Sabdi (2016) can be described briefly here. Selection of research location in North Lombok was conducted in purposive way on the basis of most cocoa growers in districts and villages. The selection of location result in two locations, i.e. Genggelang Village of Gangga District and Sokong Village of Tanjung District. The number of respondents was quoted for 30 farmers, and distributed proportionally into 22 farmers in Genggelang Village (in Gangga District) and 8 farmers in Santong Village (in Tanjung District). Respondents were selected in systematic random sampling, using the list of cocoa farmers obtained from each selected village. Data from farmers were collected through interviews using semi-structured interview format. Sabdi (2016) analyzed data for his study in a descriptive way and found factors that affect farmer decision in growing cocoa. The findings by Sabdi (2016) are then capitalized for the purpose of this paper. Firstly, the decision factors are described and explained. Secondly, farmer decisions are modelled based on decision reasons (farmer motives) in selecting cocoa as their grown crop. The result of the analysis is presented in the section of results and discussion.

\section{RESULTS AND DISCUSSION}

This main section presents decision theories related to farmers in developing countries, such as Indonesia, in the context of rural development. This is followed by a presentation on factors affecting the decision of cocoa farmers in North Lombok and the decision model of the farmers. Finally it discusses the implications of this study for extension services in the region or else.

\subsection{Decision Theories in the Context of Rural Development}

There are many decision theories, spanning from complicated to simple one, from economics end to psychology end [23]. Among them, decision theories related to rural development have focused on positive analysis, i.e. describing and explaining about what people do. This subsection explains two decision theories that complement one to another, and therefore facilitate understanding about the decision; one is theory of reallife choice and another is personal construct theory.

\subsubsection{Theory of Real-life Choice}

This research is about understanding decision making by cocoa growers in North Lombok Regency. Farmers in North Lombok, as part of Indonesian farmers, can be put in the context of farmers in developing countries. In relation to decision making, farmers in developing countries can state that they make decisions in a simplified way, in the sense that they make decisions in not so serious a way, but rather in so called half, less, or subconsciously, without paperwork or computer work. The important thing to be described here is to understand the decisions that farmers actually reach, and therefore use positive analyses [21, 22]. Many studies that apply this approach are the works of Gladwin and her colleagues [24-35]. Gladwin's theory of real-life choice is particularly applied here. The theory draws on Tversky's [36] 'elimination by aspects' and Tversky and Sattah's [37] 'preference trees'. The principles of real life choice are considered to be similar with the theory of real-life decisions [38] and choice theories [39], as well as what have been applied in selections of careers and partners in life [40]. 
Gladwin's $(1980,1983,1989)$ theory is well known as 'Theory of real-life choice', and was grounded on the observation that in real-life people make a decision in a simple way, i.e. by comparing alternatives, not ranking them. The simplified way is carried out due to limitations on cognitive capacities of decision makers to process information. The theory has two stages in reaching a decision. The first is to reduce alternatives to only several alternatives which can be managed cognitively. The reduction is done by eliminating alternatives that do not meet certain criteria set out by the decision makers. The elimination is done ra[idly, with giving less attention or awareness than ordinary ones, in the way of unconsciously or subconsciously, which Gladwin (1980) and Gladwin and Murtaugh (1980) called a preattentive process. The process in the first stage left a few alternatives in which its number is manageable by decision makers. If this stage gives only one alternative, then the decision process is completed, no more deciding process is required. In a situation where there is no alternative remaining, then decision makers may need to reconsider other criteria or take other actions. When there are still several alternatives that pass the first stage, then the decision process needs to go through to the second stage.

In the second stage decision makers consider more seriously or more consciously alternatives remaining from the first stage, and attempt to maximize subject to constraints. Each of the remaining alternatives is compared carefully to the others, in regard to every constraint or aspect selected. Decision makers choose the alternative that ranks highest on a 'major' aspect of consideration after all aspects have been passed. In the selection of crops, such as cocoa, farmers may select on the aspects of production amount, product price, or skills that farmers possess. Which one is called a major aspect among others is dependent on the farmers (as decision makers) themselves. When there is no best alternative, then the second best alternative comes into consideration, and so on. Under the condition of no best alternative decision makers will search for another alternative by employing other strategies, for example, by making order of alternatives on another aspect, lowering requirements of the same aspect, eliminating constraints, postponing decisions, and searching for other alternatives.

\subsubsection{Personal Construct Theory}

Theory of personal construct of Kelly [41, 42] is required here for the purpose of complementing the theory of real life choice $[28,29,31]$, i.e. to provide reasons or motivations of people in making decisions. The theory of personal construct assumes people as scientists. The people become scientists as they develop hypotheses about how things will work and continually test those hypotheses against their findings in their life. Once those hypothesis correctly proven, then they apply them in their life, and those people become scientists. Eventually everyone becomes a scientist in their fields. For instance, the scientists in farming are farmers; the scientists in marketing are traders; and so forth. The important question then how do we know people motivations in their behavior or their decisions? In this regard, Kelly $(1955$, p. 201) suggests that 'If you don't know what is wrong with a client, ask him; he may tell you!'. In brief, knowing people motivations or reasons in making particular decisions, is through dialogue with those people. Putting in another way, this suggestion says that we do not assume people motivations in their decisions, but ask them.

\subsection{Factors Affecting Decision on Cocoa Farm in North Lombok}

Cocoa is one of the plantation crops that farmers grow in North Lombok. It was the second highest production of plantation crop in the regency, after coconut, and before coffee [12], showing that the crop is important for the area, and was (and still is) a choice of farmers in North Lombok.

Farmers grow cocoa in North Lombok for many reasons. According to a survey in the region by Sabdi (2016), reasons for growing cocoa included: income generated by the crop, utilizing leisure time, getting privilege in being a member of a farmer group.

Income generated by cocoa in North Lombok was investigated by Sonjaya (2016) and found as much as Rp 4,830,842 per hectare. According to Sonjaya (2016) this income level is the second highest, i.e. below the income level of coconut with $\mathrm{Rp} \mathrm{5.632,005}$ per hectare. Income per hectare of cocoa is higher than candle nut, coffee, clove, banana, and seasonal crops. Therefore, this income reasoning in growing cocoa is valid and genuine. Sabdi (2016) found that the generated income was found as a major reason in growing cocoa. This is an economic reason, which indicates that cocoa farmers are rational. That is, they attempt to maximize utility (here is income) from (lowest) sacrifice they make [43-46]. Income has indeed become the biggest and most common motivation in doing business [47-51], including in this business of cocoa. Therefore, it is understandable that most cocoa farmers have income in their mind in doing this business.

The reason for growing cocoa is to be able to be a member of a group (that is farmer group) can be explained from the privilege farmers gain. From a social aspect, a member of the group can have many new friends from which information on many things, including on technical and market of cocoa, which are very useful for them, in doing the business. Furthermore, many government programs, including funding are given to farmer groups, therefore a member also receives the program and funding. Thus, at the end this social reason 
is also economic and becomes evidence of rationality of the farmer's behavior.

The other reason is utilizing leisure time in growing cocoa. This appears to be that growing cocoa is a hobby, meaning that earning income is a secondary purpose. However, farmers do mention this reason has been in condition that they already have sufficient income from other sources. Or, they have already gained income from cocoa, and the leisure time is an additional reason for growing cocoa, so additional benefit is attainable. This reason also shows that cocoa has an advantage over other crops. In other sense, farmers who grow cocoa have considered that they have time to grow the crop; otherwise they would not grow it.

There are many other possible reasons for growing cocoa, yet the farmers only mentioned at the time those reasons. For example, the suitability of cocoa with soil and climate must have been considered as important elements in growing crops, including cocoa. According to Gladwin's theory of real life choice [28, 29, 31], people make simplifications by eliminating alternatives in the condition of sub, half, or not fully conscious, in which motives or considerations appear to be nonexistent. In this sense, the cocoa farmers in North
Lombok are assumed to have had simplification in their decision making process. In addition, given only one alternative decision remained as an option then the second stage of decision making process of real life choice is not required.

\subsection{Modelling Decision of North Lombok Cocoa Growers}

From the three reasons for growing cocoa in North Lombok, decisions that farmers made can be modeled. Given the investigation was directed into reasons for growing cocoa, without investigating alternatives other than cocoa, the model presented here is indeed a simplified model. That is, the model is built without fully following the decision steps outlined in Gladwin theory $[25,28,31,52]$. Rather, the model is a confirmation that is already built in the mind of farmers. The decision model of the cocoa farmers is depicted in Figure 1. The figure shows that farmers put important consideration on three aspects, i.e. profit, social advantages, and leisure time. All of these considerations are in the nature of economics, directly (the i.e. the first reason), or indirectly (i.e. the second and third reasons).

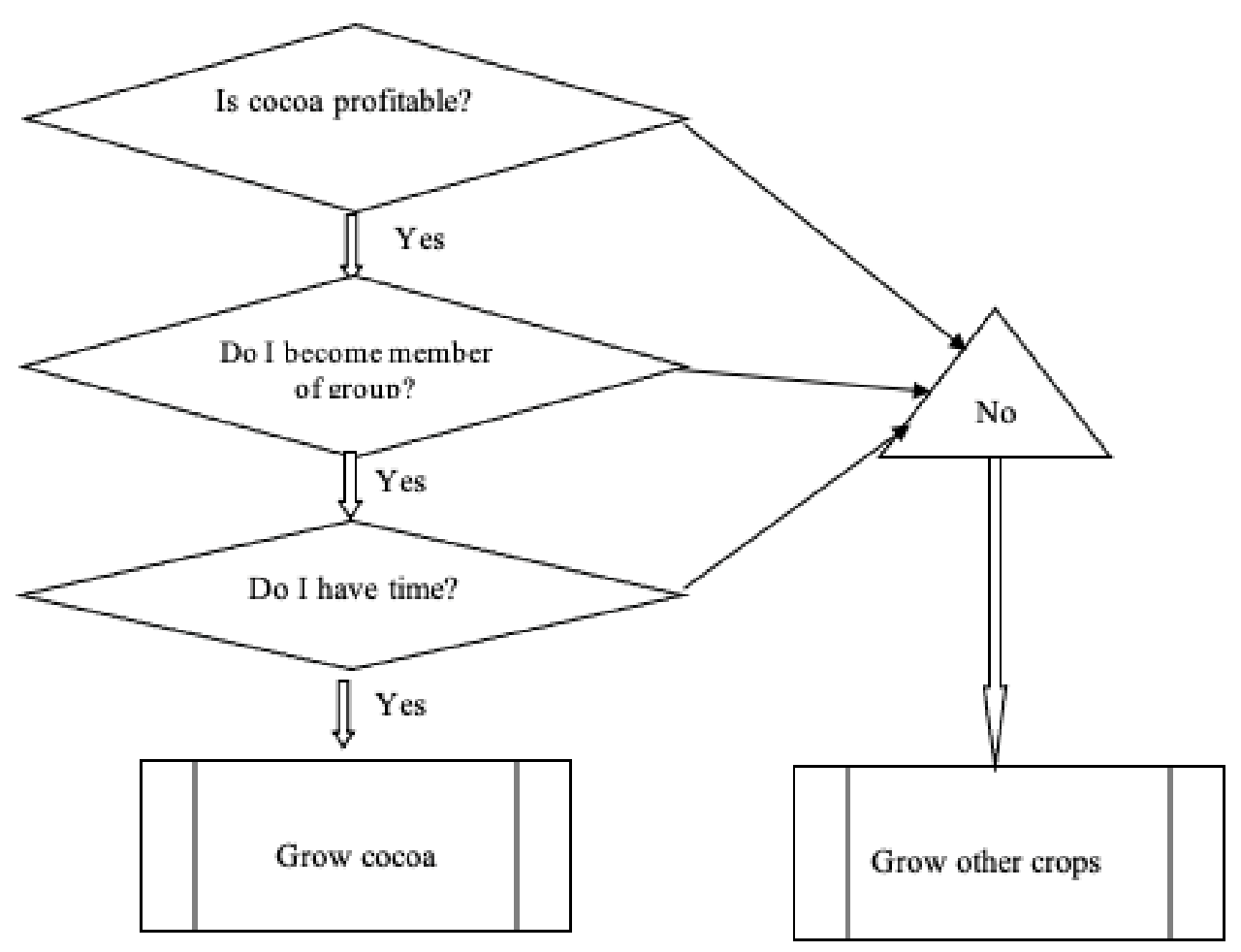

Figure 1 Decision process to grow cocoa in North Lombok 


\subsection{Implications of Findings for Extension Work}

The main lesson that can be learnt from Figure 1 of this decision making process is that promoting a crop or crops to be grown in a certain region(s) must be able to convince that the crop is profitable or bring benefits, of economic and non economic, to the people who will do it. Economic motive is one of the most important motives in people behavior [53-55]. However, non-economic motives also affect people's behavior [56-59].

However, convincing people that a crop or crops are profitable, is sometimes insufficient by just showing a calculation on paper. It will need proof in practice, for example by demonstration on the field, as frequently suggested by extension literatures [60-64].

Extension works in growing cocoa, of course, are not merely planting cocoa, but also require good practices from cocoa pre-production through to post harvest and handling [65]. The practices will bring positive and high impact for the life of the cocoa producers and other community groups and the region. However, cocoa growers also experienced several problems in the production of cocoa in North Lombok, one of them was lack of working capital to do the practice or the good one $[14,66]$. As a consequence for better cocoa production now than before, then cocoa growers will need external assistance in accessing working capital, such as from government or commercial lending institutions. In this regard, credit disbursement and its follow up activities need to be implemented in a better way than the conventional practice, to assure effectiveness of the financing activities and the credit itself [67].

\section{CONCLUSION}

The conclusion from this study is that there are three reasons for farmers to grow cocoa in North Lombok Regency, included, generated income, social relation, and available time. The reasons show farmers are rational in sacrificing their resources and expecting the highest gain from their sacrifice, for which income is the important reason in their behavior and other two latter reasons were at the end essentially economic for the cocoa producers. These three reasons are then utilized to build a cocoa farmer decision model, showing the aspects of the crop choice and the steps in reaching the decision. This result also implies for extension activities, to be implemented in an effective way, by paying attention to economic motive in particular and other accompanying motives in the behavior of farmers (or other people groups).

\section{ACKNOWLEDGMENTS}

We highly appreciate any support and assistance in accomplishing this study, both from within and the external to the University of Mataram.

\section{REFERENCES}

[1] BPS 2015 Analisis Tematik ST2013 Subsektor Ketahanan, Kemandirian, dan Kedaulatan Pangan Indonesia, BPS, Jakarta.

[2] Syahyuti, Sunarsih, Wahyuni, S, Sejati, W K, and Azis, M. 2015 Kedaulatan Pangan Sebagai Basis Untuk Mewujudkan Ketahanan Pangan Nasional (Food Sovereignty as the Basis to Realize National Food Security), Forum Penelitian Agro Ekonomi $33,95-109$.

[3] Menteri Pertanian RI 2020 Rencana Strategis Kementerian Pertanian 2020-2024, Kementerian Pertanian Republik Indonesia, Jakarta.

[4] Ng, D, and Siebertb, J W. 2009 Toward Better Defining the Field of Agribusiness Management, International Food and Agribusiness Management Review 12, 123-142.

[5] Cramer, G L, Jensen, C W, and Southgate, D D J 2001 Agricultural Economics and Agribusiness, 8th ed., John Wiley \& Sons, New York.

[6] Davis, J, and Goldberg, R 1957 A Concept of Agribusiness, Alpine Press, Boston.

[7] Saragih, B 2004 Pembangunan pertanian dengan paradigma sistem dan usaha agribisnis, Jakarta.

[8] Imansyah, N. 20211.106 hektare lahan di Lombok Utara siap ditanami padi, In Antara News, mataram.antaranews.com, Mataram.

[9] Dinham, B. 2003 Growing vegetables in developing countries for local urban populations and export markets: problems confronting small-scale producers, Pest Management Science 59, 575-582.

[10] Gyasi, E, Agyepong, G T, Ardayfioschandorf, E, Enukwesi, L, Nabila, J S, and Owusubennoah, E. 1995 Production Pressure and EnvironmentalChange in the Forest-Savanna Zone of Southern Ghana, Global Environmental Change-Human and Policy Dimensions 5, 355-366.

[11] Savadogo, K, Reardon, T, and Pietola, K. 1998 Adoption of improved land use technologies to increase food security in Burkina Faso: Relating animal traction, productivity, and non-farm income, Agricultural Systems 58, 441-464.

[12] BPS Lombok Utara 2021 Kabupaten Lombok Utara Dalam Angka 2021 (North Lombok Regency in 
Figures 2021), Badan Pusat Statistik Kabupaten Lombok Utara (Central Body of Statistics of North Lombok Regency), Tanjung.

[13] Sonjaya, S. 2016 Penerapan sistem agroforestri pada Hutan Rakyat di Kecamatan Gangga Kabupaten Lombok Utara (Agroforestry system implementation in people forest in Gangga District, North Lombok Regency), In Dryland Resource Management, University of Mataram, Mataram.

[14] Sabdi. 2016 Faktor-faktor yang mempengaruhi keputusan petani terhadap usahatani kakao di Kabupaten Lombok Utara (Factors affecting farmer decision in cocoa farm in North Lombok Regency), In Dryland Resource Management, University of Mataram, Mataram.

[15] Pohanková, A. 2009 Motivation Program as Basis for Successful Motivating in the Organization, Human Resources Management \& Ergonomics 3.

[16] Mihalic, S, Irwin, K, Fagan, A, Ballard, D, and Elliott, D. 2004 Successful Program Implementation: Lessons From Blueprints, Juvenile Justice Bulletin, 1-11.

[17] Howard, N L, Marshall, P, and Swatman, P A. 2010 Reconceptualising Motivation in Adoption and Acceptance Research: Back to Basics, In 21st Australasian Conference on Information Systems, ACIS, Brisbane.

[18] Cheek, J. 2005 The practice and politics of qualitative research, In The Sage Handbook of Qualitative Research (Denzin, N K, and Lincoln, Y S, Eds.) $3^{\text {rd }}$ ed., pp 387-410, Sage Publications, Thousand Oaks, California.

[19] Patton, M Q 2002 Qualitative research and evaluation methods, 3 ed., Sage Publications, Thousand Oaks, California.

[20] Silverman, D 2000 Doing qualitative research: A practical handbook, Sage Publications, London.

[21] Schoemaker, P J H. 1991 The Quest for Optimality - a Positive Heuristic of Science, Behavioral and Brain Sciences 14, 205-214.

[22] Roumasset, J A 1981 Positive methods of agricultural analysis, The Australian National University, Canberra.

[23] Hammond, K R, McClelland, G H, and Mumpower, J 1980 Human judgment and decision making. Theories, methods, and procedures, Praeger, New York.

[24] Gladwin, C H. 1976 View of Plan Puebla Application of Hierarchical Decision Models,
American Journal of Agricultural Economics 58, 881-887.

[25] Gladwin, C H. 1977 A model of farmers' decision to adopt the recommendations of Plan Puebla, Stanford University, Stanford.

[26] Gladwin, C H. 1979 Production function and decision models: complementary models, American Ethnologist 6, 653-674.

[27] Gladwin, C H. 1979 Cognitive strategies and adoption decisions - Case study of non-adoption of an agronomic recommendation, Economic Development and Cultural Change 28, 155-173.

[28] Gladwin, C H. 1980 A theory of real-life choice: applications to agricultural decision, In Agricultural Decision Making: Anthropological Contributions to Rural Development (Bartlett, P F, Ed.), pp 45-85, Academic Press, New York.

[29] Gladwin, C H. 1983 Contributions of Decision-Tree Methodology to a Farming Systems Program, Human Organization 42, 146-157.

[30] Gladwin, C H. 1984 Frontiers in Hierarchical Decision Modeling - Introduction, Human Organization 43, 198-198.

[31] Gladwin, C H 1989 Ethnographic decision tree modelling, Sage Publications, Newbury Park, California.

[32] Gladwin, C H, and Butler, J. 1982 Gardening - a Survival Strategy for the Small, Part-Time Florida Farm, Proceedings of the Florida State Horticultural Society 95, 264-268.

[33] Gladwin, C H, and Butler, J. 1984 Is Gardening an Adaptive Strategy for Florida Family Farmers, Human Organization 43, 208-216.

[34] Gladwin, C H, Peterson, J S, and Mwale, A C. 2002 The quality of science in participatory research: A case study from eastern Zambia, World Development 30, 523-543.

[35] Gladwin, C H, Thomson, A M, Peterson, J S, and Anderson, A S. 2001 Addressing food security in Africa via multiple livelihood strategies of women farmers, Food Policy 26, 177-207.

[36] Tversky, A. 1972 Elimination by aspects: a theory of choice, Psychological Review 79, 281-299.

[37] Tversky, A, and Sattah, S. 1979 Preference trees, Psychological Review 86, 542-575.

[38] Welch, J R. 2012 Real-Life Decisions and Decision Theory, In Handbook of Risk Theory: Epistemology, Decision Theory, Ethics, and Social Implications of 
Risk (Hillerbrand, R, Sandin, P, and Peterson, M, Eds.), pp 545-573, Springer, Dordrecht

[39] Johnson, E J. 2013 Choice theories: What are they good for?, J of Consumer Psychology 23, 154-157.

[40] Schindler, I, and Tomasik, M J. 2010 Life choices well made: How selective control strategies relate to career and partner decision processes, Motivation and Emotion 34, 168-183.

[41] Kelly, G A 1991 The psychology of personal constructs, Routledge, London.

[42] Kelly, G A 1955 The psychology of personal constructs, Norton, New York.

[43] McIver, J 2001 Micro economics, McGraw-Hill, Roseville, NSW, Australia.

[44] Sjah, T 2010 Ekonomi Pertanian (Agricultural Economics), Mataram University Press, Mataram.

[45] Casavant, K L, Infanger, C L, and Bridges, D E 1999 Agricultural economics and management, Prentice Hall, Upper Saddle River, New Jersey.

[46] Tregarthen, T 1996 Economics, Worth Publishers, New York.

[47] Truett, L J, and Truett, D B 1995 Managerial Economics, 5 ed., South-Western College, Cincinnati.

[48] Aaker, D A 1992 Strategic Market Management, John Wiley \& Sons, New York.

[49] Castle, E N, Becker, M H, and Nelson, A G 1987 Farm business management: the decision making process, Mac Millan, New York.

[50] Obst, W J 1986 Practical Farm Business Management, Reston, Virginia.

[51] Aaker, D A, and Moorman, C 2017 Strategic Market Management, 11 ed., Wiley, New York.

[52] Gladwin, H, and Murtaugh, M. 1980 The attentivepreattentive distinction in agricultural decision making, In Agricultural Decision Making: Anthropological Contributions to Rural Development (Bartlett, P F, Ed.), pp 115-135, Academic Press, New York.

[53] Stracca, L. 2004 Behavioral finance and asset prices: Where do we stand?, Journal of Economic Psychology 25, 373-405.

[54] Neumann, J V, and Morgenstern, O 2004 Theory of games and economic behavior, $60^{\text {th }}$ Anniversary ed., Princeton University Press, Princeton.

[55] Assael, H 1995 Consumer Behavior and Marketing Action, 5 ed., South-Western College, Cincinnati.
[56] Barber, B M, and Odean, T. 2008 All that glitters: The effect of attention and news on the buying behavior of individual and institutional investors, Review of Financial Studies 21, 785-818.

[57] Antle, J M, Capalbo, S M, Elliott, E T, Hunt, H W, Mooney, S, and Paustian, K H. 2001 Research needs for understanding and predicting the behavior of managed ecosystems: Lessons from the study of agroecosystems, Ecosystems 4, 723-735.

[58] Bazerman, M H, and Tenbrunsel, A. 1998 The role of social context on decisions: Integrating social cognition and behavioral decision research, Basic and Applied Social Psychology 20, 87-91.

[59] Parker, C H. 1918 Motives in economic life, The American Economic Review 8, 212-231.

[60] Waage, J. 1996 "Yes, but does it work in the field?" - The challenge of technology transfer in biological control, Entomophaga 41, 315-332.

[61] Marsh, S P, Pannell, D J, and Lindner, R K. 2004 Does agricultural extension pay? A case study for a new crop, lupins, in Western Australia, Agricultural Economics 30, 17-30.

[62] Arboleya, J, and Restaino, E. 2004 Agricultural extension models in South America: A description of systems in use in Argentina, Brazil, Paraguay and Uruguay, Horttechnology 14, 14-19.

[63] Black, A W. 2000 Extension theory and practice: a review, Australian Journal of Experimental Agriculture 40, 493-502.

[64] Von Kessel, W C. 1999 Agricultural extension services: Looking back on more than 30 years of successful work, Zuckerindustrie 124, 608-610.

[65] Zainuri, Sjah, T, Prameswari, N, Werdiningsih, W, and Tarmizi. 2021 Good agricultural and postharvest handling practices of Cocoa pods in Lombok to meet Cocoa bean quality for the global market, In IOP Conf. Series: Earth and Environmental Science, IOP Publishing, Mataram.

[66] Atmaja, D N M. 2012 Strategi pengembangan agribisnis kakao di Pulau Lombok (Strategies for developing cocoa in Lombok Island), In Dryland Resource Management, University of Mataram, Mataram.

[67] Sjah, T, Cameron, D, and Russell, I. 2006 Searching for a better credit system to help improve farmers' income: A reflection from study on agricultural credit users in Lombok, Indonesia, In Readings in World Development: Growth and Development in the Asia Pacific (Roy, K C, and Chatterjee, S, Eds.), pp 115-128, Nova Science, New York. 